\title{
The Possible Role of Adipokines in HCV Associated Hepatocellular Carcinoma
}

\author{
Usama M El-Daly¹, Magdy M Saber², Mona S Abdellateif', Hanan R Nassar², \\ Alfred E Namour ${ }^{2}$, Yahia M Ismail ${ }^{2}$, Abdel-Rahman N Zekri ${ }^{4 *}$
}

\begin{abstract}
Background: Adipokines play an important role in the regulation of inflammation and tumor progression. Aim: Assessment of the possible role of adiponectin, leptin and visfatin in HCV associated hepatocellular carcinoma (HCC). Methods: patients were classified into 85 patients with HCV associated HCC, 100 patients with chronic hepatitis C viral (HCV) infection compared to 50 normal control (NC) subjects. All subjects included in the study were assessed for HCV infection by seropositive HCV antibodies, as well as HCV RNA by RT-PCR. Serum levels of adiponectin, leptin and visfatin were assessed using enzyme linked immunosorbent assay (ELISA). The data were correlated to the relevant clinic-pathological features of the patients, and the overall survival (OS) rate. Results: There was a significant difference in the serum levels of adiponectin and visfatin among HCC, HCV and NC groups $(\mathrm{P}<0.001)$. The serum levels of leptin and alpha fetoprotein (AFP) were significantly higher in $\mathrm{HCC}$ group $(\mathrm{P}<0.001)$. There was a significant association between the serum level of adiponectin and advanced Child class liver cirrhosis $(\mathrm{P}=0.03)$, as well as with poor performance status (ECOG, $\mathrm{P}=0.02$ ). Serum leptin associated significantly with the number of lesions in the liver $(\mathrm{P}=0.006)$, visfatin associated with increased mortality rate $(\mathrm{P}<0.001)$. Adiponectin, leptin and visfatin associated significantly with liver cirrhosis in HCV patients $(\mathrm{P}<0.01)$. Leptin achieved the highest sensitivity $(98.8 \%)$. visfatin achieved the highest specificity (100\%) and PPV (100\%) for detection of HCC. The combination of serum leptin and visfatin for the diagnosis of HCV associated HCC showed sensitivity, specificity, PPV, NPV and accuracy (100\%, 96.6\%, 93.4\%, 100\% and 97.4\%; respectively). Conclusion: Adiponectin, leptin and visfatin have an important role(s) in the pathogenesis of HCV associated HCC.
\end{abstract}

Keywords: Adiponectin- leptin- visfatin- adipokines- HCC- HCV

Asian Pac J Cancer Prev, 21 (3), 599-609

\section{Introduction}

Hepatocellular carcinoma (HCC) is the third most common cause of cancer related death worldwide (Siegel et al., 2017). In Egypt, HCC ranks the first among cancers in males $(33.6 \%)$, and the 2 nd in females after breast cancer $(13.5 \%)$, with HCV genotype 4 is the most prevalent underlying cause (Zekri et al., 2001; Ibrahim et al., 2014). The most commonly aberrant gene expression in Egyptian HCC patients are related to virus response such as; ISGF3G, virus-induced signaling adapter VISA and FGR (Zekri et al., 2012). The non-alcoholic fatty liver disease (NAFLD) is considered an important cause of end stage liver disease and HCC in the developed countries with a worldwide prevalence ranging from $6 \%$ to $35 \%$ (Said and Ghufran, 2017).

Adipose tissue has an important role in the pathogenesis of hepatic diseases, since it secretes pro- and anti-inflammatory cytokines called adipokines which include e.g. adipocytokines, leptin, visfatin, resistin, chemerin, retinol-binding protein 4 and irisin (Boutari et al., 2018). Leptin, visfatin and adiponectin play a role in the regulation of inflammation, tumor microenvironment and progression of hepatic diseses (Deng et al., 2016). Changes in these adipokines levels are associated with increased risks of breast (Macis et al., 2014; Ye et al., 2014), colorectal (Zekri et al., 2015; Otani et al., 2017), liver (Song and Gu, 2015) and pancreatic cancers (Stolzenberg-Solomon et al., 2015).

Adiponectin is a hormone released by the adipose tissue, which improves the hepatic and peripheral insulin resistance (IR). It has anti-inflammatory and hepato-protective activities (Polyzos et al., 2010), as it stimulates the secretion of anti-inflammatory cytokines such as interleukin-10 (IL-10) and IL-1 receptor antagonist. It also suppresses the release of

${ }^{1}$ Department of Medical Oncology, Damietta Oncology Center, Damietta, ${ }^{2}$ Department of Medical Oncology and Malignant Hematology, ${ }^{3}$ Medical Biochemistry and Molecular Biology, Cancer Biology Department, ${ }^{4}$ Molecular Virology and Immunology Unit, Department of Cancer Biology, National Cancer Institute, Cairo University, Cairo, Egypt. *For Correspondence: ncizekri@yahoo.com 
pro-inflammatory cytokines such tumor necrosis factor $\alpha$ (TNF- $\alpha$ ), IL- 6 and interferon- $\gamma$. this will Consequently lead to blocking the activation of the nuclear factor $\kappa B$ (Boutari et al., 2018).

Leptin is expressed mainly in adipose tissue, and it is involved in the regulation of energy homeostasis, angiogenesis, hematopoiesis and neuroendocrine function (Matarese et al., 2010). In the liver, it decreases the expression of sterol regulatory element-binding transcription factor 1 (SREBP-1) (Kakuma et al., 2000), which regulates the expression of genes required for glucose metabolism, fatty acid, and lipid production (Ferre and Foufelle, 2010). In addition, it has a key-role in hepatic fibrogenesis by up-regulating the expression level of the transforming growth factor $\beta 1$, with subsequent activation of stellate cells, and increasing the fibrogenic response in the liver (Ikejima et al., 2001).

Visfatin is another cytokine which is secreted by the adipose tissue. It is called pre-B cell colony-enhancing factor, and it is a pro-inflammatory cytokine that stimulates TNF- $\alpha$ and IL-6 secretion (Moschen et al., 2007). It is also involved in the development of NAFLD by regulating hepatic inflammation as well as glucose homeostasis and IR (Saxen and Anania, 2015).

Therefore, we assessed serum levels of adiponectin, leptin and visfatin in HCC and chronic HCV patients compared to healthy individuals matched for age and sex as control. We also evaluated their relation with the survival rates of patients. In addition, correlations between these markers and the relevant clinic-pathological features of the patients.

\section{Materials and Methods}

\section{Patients}

This retrospective cohort study included 85 patients with histo-pathologically confirmed $\mathrm{HCC}$ on top of hepatitis $\mathrm{C}$ virus (HCV), and 100 patients with chronic $\mathrm{HCV}$, compared to 50 matched normal controls (NC). Patients were diagnosed and treated at the National Cancer Institute (NCI), Kasr Al Ainy faculty of medicine, Cairo University, and from Damietta Oncology Centre outpatient clinics, during the period between October 2012 and January 2014. The NC subjects had normal serum ALT, AST levels and all were seronegative for HBV and HCV antibodies.

The HCC and HCV patients were $\mathrm{HCV} /$ genotype 4 positive by seropositive $\mathrm{HCV}$ antibodies (EIAgen HCV Ab (v.4), code: 071064, adaltis. Milano Italy) as well as, HCV RNA by RT-PCR (artus HCV RT-PCR Kits CE, 4518265, QIAGEN GmbH, QIAGEN Strasse 1, D-40724 Hilden). Genotyping was done through amplification of the biotinylated complimentary DNA (cDNA) product of the core region of the HCV RNA using the HCV Amplification 2.0 kit (LiPA; Bayer HealthCare, Tarrytown, NY, USA). Then the product was processed using the VERSANT HCV Genotype 2.0 assay (LiPA; Bayer HealthCare, Eragny, France), according to the manufacturer's instructions (Stuyver et al., 1996).

All patients were subjected to full history taking, clinical and radiological examination, as well as serological examination including AST, ALT, total and direct bilirubin, serum albumin-prothrombin time and INR), Complete blood picture, Kidney function tests, Random blood sugar and alpha feto-protein. Patients were confirmed for HCC daignosis by abdominal ultrasonography and triphasic CT abdomen, they had not received chemotherapy, targeted therapy or radiotherapy, also they had not undergone hepatic resection or any local ablative therapy like RFA, PEI or TACE.

Patients were excluded from the study if they had; 1) causes of liver disease other than HCV, 2) Hepatic viral infection other than HCV and 3) Patients with other malignancies.

Body mass index (BMI) was calculated by dividing the body weight in kilograms by the square of the patient's height in meters (WHO, Fact sheet No 164, 2016).

Histopathological diagnosis and grading were performed according to classification criteria of the World Health Organization (WHO/HIV/2016), and staging was done according to the American Joint Committee on Cancer (Amin et al., 2017).

\section{Assessment of Adipocytokines concentrations in serum samples}

Serum sample collection: Blood samples were collected in serum separator tubes (SST) and allowed to clot for 10 to 20 minutes at room temperature. Samples were then centrifuged at $1,000 \mathrm{~g}$ for 10 minutes, and the serum was aliquot and stored at $-20^{\circ} \mathrm{C}$ until use for protein evaluations.

Serum levels of Adiponectin, leptin and vesfatin were assessed using the enzyme linked immunosorbent assay (ELISA), according to manufacturer's instructions (Human Adiponectin Platinum ELISA Affymetrixe Bioscience), Human Leptin (LEP) ELISA Kit WKEA MED SUPPLIES and RayBio Human Visfatin Enzyme Immunoassay Kit RayBiotech; respectively). The tests were performed using a microplate reader (Tecan) at 450 nm wavelength.

\section{Statistical methods}

The data were analyzed using SPSS version 22 and graph pad prism 7. Non-parametric Mann-Whitney and Kruskal-Wallis test were used to compare markers among groups, and its association to clinic-pathological variables. Patients and their tumor characteristics were analyzed using Chi-square test. The Area under the receiver operating curve (ROC) was calculated for each marker to investigate the best cut-off level for diagnosis of HCC. The association with overall survival was analyzed by log-rank test and Cox-regression for multivariate analysis. All p-values were considered statistically significant at $<0.05$

\section{Results}

\section{Patients' characteristics}

The mean ages of the HCC, chronic HCV and control groups were (60.7, 58 and 57; respectively). The mean weight was $(75.8,79.3$ and $76.7 \mathrm{Kg}$; respectively), and the BMI was $(27.2,28.4$ and 28.6; respectively, Table 1).

Out of the 85 patients in HCC group, there were 68(80\%) 
Table 1. Baseline Characteristics of the 3 Studied Groups

\begin{tabular}{lcccc}
\hline Variable & HCC (85) & HCV $(100)$ & $\begin{array}{c}\text { Normal } \\
\text { control }(50)\end{array}$ & $\mathrm{p}$-value \\
\hline Age (years) & $60.7 \pm 8.8^{*}$ & $58.1 \pm 8.6$ & $57.7 \pm 8.2$ & 0.17 \\
Weight & $75.8 \pm 14.4$ & $79.3 \pm 13.3$ & $76.7 \pm 16.8$ & $\mathrm{P}=0.26^{\mathrm{x}}$ \\
Height (cm) & $166.71 \pm 8.5$ & $164.33 \pm 8.7$ & $165.20 \pm 15.6$ & 0.13 \\
BMI & $27.2 \pm 4.95$ & $28.4 \pm 4.1$ & $28.6 \pm 6.6$ & $\mathrm{P}=0.21^{\mathrm{x}}$ \\
Diabetes & $14\left(16.5^{\circ}\right)$ & $30\left(30.0^{\circ}\right)$ & $16\left(32.0^{\circ}\right)$ & $\mathrm{P}=0.054^{\mathrm{y}}$ \\
mellitus & & & & \\
HGB & $12.2 \pm 1.9^{\mathrm{a}}$ & $13.3 \pm 1.6^{\mathrm{b}}$ & $14.1 \pm 1.3^{\mathrm{c}}$ & $\mathrm{P}<0.001^{\mathrm{x}}$ \\
WBCs & $6.3 \pm 4.7$ & $5.6 \pm 2.0$ & $6.8 \pm 1.5$ & $\mathrm{P}=0.07^{\mathrm{x}}$ \\
Platelets & $135.3 \pm 72.7^{\mathrm{a}}$ & $171.5 \pm 71.17^{\mathrm{b}}$ & $306.2 \pm 82.3^{\mathrm{c}}$ & $\mathrm{P}<0.001$ \\
Cirrhosis & $85(100.0)$ & $48(48.0)$ & $\mathrm{NA}$ & $\mathrm{P}<0.001^{\mathrm{y}}$ \\
Albumin & $2.96 \pm 0.59$ & $3.8 \pm 0.63$ & $\mathrm{NA}$ & $\mathrm{P}<0.001^{\mathrm{z}}$ \\
ALT & $63.9 \pm 35.5^{\mathrm{a}}$ & $59.9 \pm 47.5^{\mathrm{b}}$ & $12.5 \pm 4.3^{\mathrm{c}}$ & $\mathrm{P}<0.001^{\mathrm{x}}$ \\
AST & $89.7 \pm 44.1^{\mathrm{a}}$ & $63.3 \pm 47.7^{\mathrm{b}}$ & $21.7 \pm 6.2^{\mathrm{c}}$ & $\mathrm{P}<0.001^{\mathrm{x}}$ \\
INF & $64.0 \pm 13.3$ & $86.6 \pm 17.8$ & $\mathrm{NA}$ & $\mathrm{P}<0.001^{\mathrm{z}}$ \\
Bilirubin & $2.2 \pm 2.4$ & $0.78 \pm 0.3$ & $\mathrm{NA}$ & $\mathrm{P}<0.001^{\mathrm{z}}$ \\
\hline
\end{tabular}

*, Data are expressed as mean $\pm \mathrm{SD}$; Groups bearing different initials are significantly different; $x$, Kruskal-Wallis test; y, Chi square test; $z$, Mann-Whitney test

males, and $17(20 \%)$ females. ECOG performance status was 0 in $16(18.8 \%)$ of patients, ECOG 1 in $22(25.9 \%)$, ECOG 2 in 34 (40.0\%), and ECOG 3 in $13(15.3 \%)$ patients. Twenty-seven $(31.8 \%)$ patients were normal weight, and 38 (44.7\%) were overweight, 14 (16.5\%) were class I obesity, and 6 (7.1\%) were class II obesity. Fourteen patients $(16.5 \%)$ were diabetic, and $71(83.5 \%)$ were non diabetic. All patients had liver cirrhosis. Twenty patients $(23.5 \%)$ were score A Child-Turcotte-Pugh, 45 $(52.9 \%)$ were score B and 20 patients $(23.5 \%)$ were score C. Nineteen patients $(22.4 \%)$ had tumor size less than 5 $\mathrm{cm}$, meanwhile $66(77.6 \%)$ patients had tumor size more than $5 \mathrm{~cm}$. Barcelona Clinic Liver Cancer (BCLC) stage was $\mathrm{A}$ in $3(3.5 \%)$, B in $27(31.8 \%), \mathrm{C}$ in $43(50.6 \%)$, and $\mathrm{D}$ in $12(14.1 \%)$ patients. thirty-five $(41.2 \%)$ patients had HCC in the right lobe, $18(21.2 \%)$ in the left lobe, and 32 $(37.6 \%)$ in both lobes. Twenty patients $(23.5 \%)$ had single

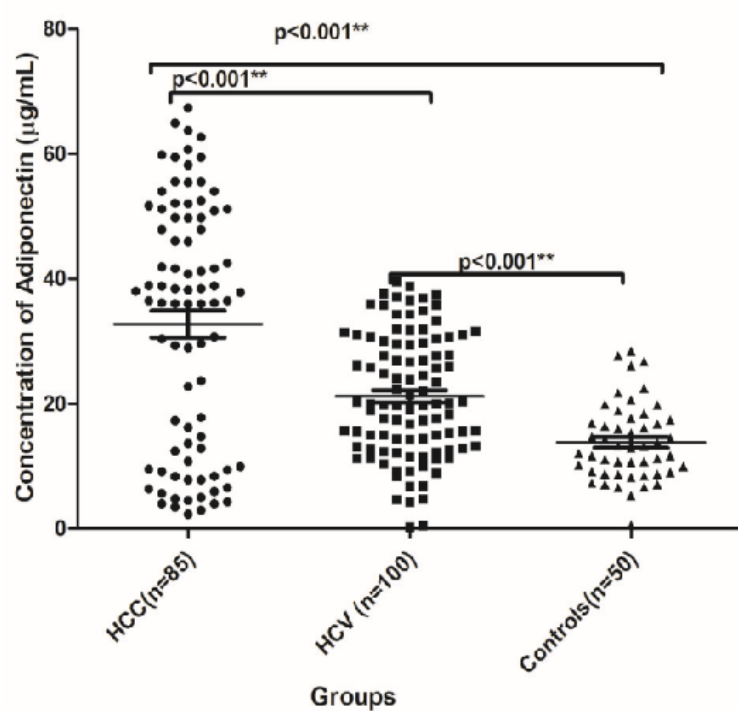

Figure 1. The Serum Level of Adiponectin $(\mu \mathrm{g} / \mathrm{ml})$ among $\mathrm{HCC}, \mathrm{HCV}$ and NC Groups.

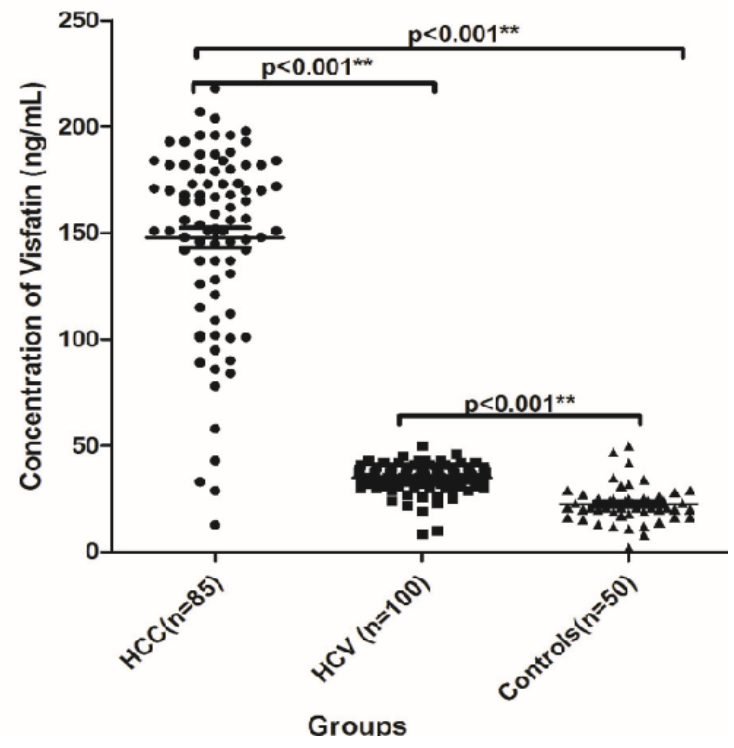

Figure 2. The Serum Level of Visfatin (ng/ml) among HCC, HCV and NC Groups

lesion, six (7.1\%) had bifocal lesions, and 59 (69.4\%) had multiple lesions. Distant metastasis was present in 14 (16.5\%) patients only. At the end of the study 15 (17.6\%) patients were alive, and 70 (82.4\%) were dead (Table 2).

Serum levels of the studied markers in the patients' groups

There was a significant difference in the serum levels of adiponectin (median $\mu \mathrm{g} / \mathrm{ml}$ and range) among $\mathrm{HCC}$, HCV and NC groups; 36.5 (2.3- 67.4), 20.1 (0.30- 39.6) and 13.1 (28.4- 553.2); respectively, $(\mathrm{P}<0.001$, Figure 1). Also there was significant difference in the serum level of visfatin (median $\mathrm{ng} / \mathrm{ml}$ and range) among $\mathrm{HCC}, \mathrm{HCV}$ and NC groups; 156.0 (12.7- 218), 35.0 (8.5- 50) and 21.0 (2.0- 50); respectively, $(\mathrm{P}<0.001$, Figure 2). There was a significant increase in the serum level of leptin in HCC group which was $4.19 \mathrm{ng} / \mathrm{ml}(0.9-19.8, \mathrm{P}<0.001)$, whereas there was no significant difference in its level between $\mathrm{HCV}$ and the NC groups; it was $2.2 \mathrm{ng} / \mathrm{ml}$

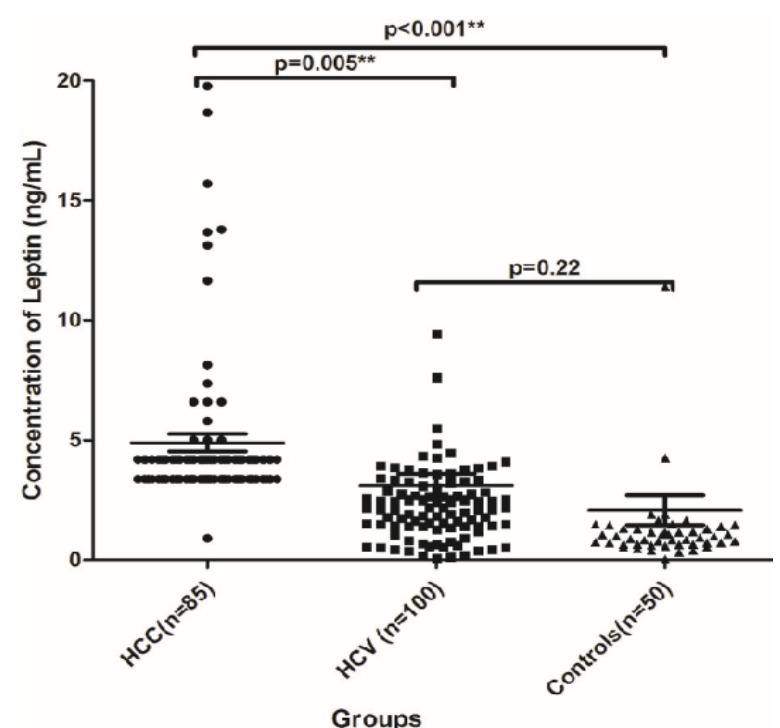

Figure 3. The Serum Level of Leptin $(\mu \mathrm{g} / \mathrm{ml})$ among HCC, HCV and NC Groups. 
Table 2. Clinico-Pathological Features of HCC Patients

\begin{tabular}{|c|c|}
\hline Parameter (85) & Number $(\%)$ \\
\hline Age & $60.7 \pm 8.8(43-84)$ \\
\hline \multicolumn{2}{|l|}{ Gender } \\
\hline Male & $68(80)$ \\
\hline Female & $17(20)$ \\
\hline \multicolumn{2}{|l|}{ Residence } \\
\hline Urban & $24(28.2)$ \\
\hline Rural & $61(71.8)$ \\
\hline \multicolumn{2}{|c|}{ Performance status (ECOG) } \\
\hline 0 & $16(18.8)$ \\
\hline 1 & $22(25.9)$ \\
\hline 2 & $34(40.0)$ \\
\hline 3 & $13(15.3)$ \\
\hline \multicolumn{2}{|l|}{ BMI category } \\
\hline Normal Weight & $27(31.8)$ \\
\hline Overweight & $38(44.7)$ \\
\hline Class I obesity & $14(16.5)$ \\
\hline Class II obesity & $6(7.1)$ \\
\hline \multicolumn{2}{|c|}{ Diabetes Mellitus (DM) } \\
\hline Yes & $14(16.5)$ \\
\hline No & $71(83.5)$ \\
\hline \multicolumn{2}{|l|}{ Cirrhosis } \\
\hline Yes & $0(0.0)$ \\
\hline No & $85(100.0)$ \\
\hline \multicolumn{2}{|l|}{ Schistosomiasis } \\
\hline Yes & $51(60 \%)$ \\
\hline No & $43(40 \%)$ \\
\hline \multicolumn{2}{|l|}{ Ascites } \\
\hline Yes & $31(36.5 \%)$ \\
\hline No & $54(63.5 \%)$ \\
\hline \multicolumn{2}{|c|}{ Child-Turcotte-Pugh score } \\
\hline A & $20(23.5 \%)$ \\
\hline $\mathrm{B}$ & $45(52.9 \%)$ \\
\hline $\mathrm{C}$ & $20(23.5 \%)$ \\
\hline \multicolumn{2}{|l|}{ Tumor size (cm) } \\
\hline$\leq 5 \mathrm{~cm}$ & $19(22.4)$ \\
\hline$>5 \mathrm{~cm}$ & $66(77.6)$ \\
\hline \multicolumn{2}{|l|}{ Affected lobe } \\
\hline Right & $35(41.2 \%)$ \\
\hline Left & $18(21.2 \%)$ \\
\hline Both & $32(37.6 \%)$ \\
\hline \multicolumn{2}{|l|}{ Number of lesions } \\
\hline Single & $20(23.5 \%)$ \\
\hline Bifocal & $6(7.1 \%)$ \\
\hline Multiple & $59(69.4 \%)$ \\
\hline \multicolumn{2}{|l|}{ Metastasis } \\
\hline M0 & $71(83.5 \%)$ \\
\hline M1 & $14(16.5 \%)$ \\
\hline
\end{tabular}

Table 2. Continued

\begin{tabular}{lc}
\hline Parameter (85) & Number (\%) \\
\hline BCLC & \\
A & $3(3.5)$ \\
B & $27(31.8)$ \\
C & $43(50.6)$ \\
D & $12(14.1)$ \\
Mortality & \\
Alive & $15(17.6)$ \\
Dead & $70(82.4)$ \\
\hline
\end{tabular}

(0.07-34.0) versus $0.99 \mathrm{ng} / \mathrm{ml}$ (0.02- 22.0); respectively $(\mathrm{P}=0.22$, Figure 3$)$. AFP was also significantly increased in the HCC group as it was $272.0 \mathrm{ng} / \mathrm{ml}(1.9-11884$, $\mathrm{P}<0.001)$ compared to the other groups. However, no significant difference was found in its level between the $\mathrm{HCV}$ and the NC groups where its level was 7.5 (1.0- 146) and 5.4 (2.6-9.6) ng/ml; respectively $(\mathrm{P}<0.05$, Table 3$)$.

Correlation between the studied markers and the clinicopathological features of the HCC patients

There was significant association between increased serum level of adiponectin and advanced Child class liver cirrhosis $(\mathrm{P}=0.03)$, and poor performance status (ECOG) of the patients $(\mathrm{P}=0.02)$. Leptin associated significantly with the number of hepatic lesions $(\mathrm{P}=0.006)$, Whereas
A

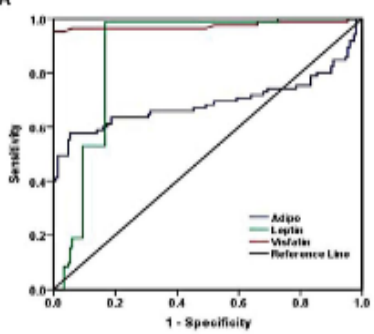

c
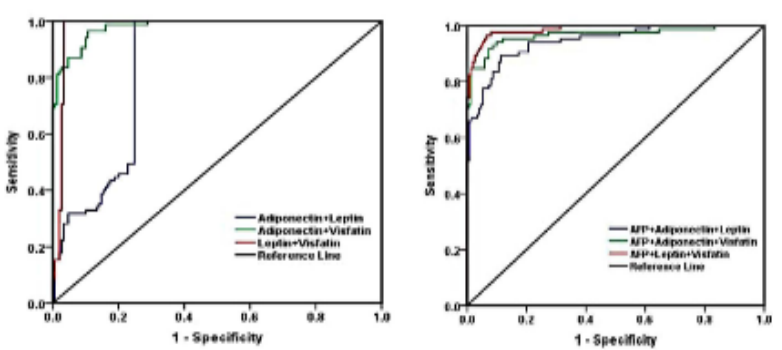

B

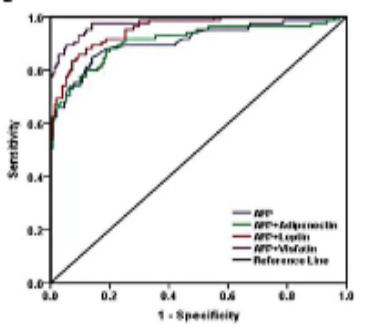

E

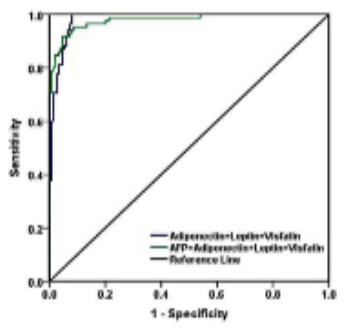

Figure 4. ROC Curve Analysis of the Serum Adiponectin, Leptin, Visfatin and AFP for the Diagnosis of HCC Patients. 
Table 3. Serum Levels of the Studied Markers among the Different Investigated Groups

\begin{tabular}{|c|c|c|c|c|}
\hline Marker & $\begin{array}{c}\mathrm{HCC} \\
(85)\end{array}$ & $\begin{array}{l}\mathrm{HCV} \\
(100)\end{array}$ & $\begin{array}{l}\mathrm{NC} \\
(50)\end{array}$ & $\begin{array}{c}\mathrm{p}- \\
\text { value }\end{array}$ \\
\hline \multicolumn{5}{|c|}{ Adiponectin } \\
\hline $\operatorname{Median}(\mu \mathrm{g} / \mathrm{ml})$ & $36.5^{\mathrm{a}}$ & $20.1^{\mathrm{b}}$ & $13.1^{\mathrm{c}}$ & \\
\hline Range & $2.3-67.4$ & $0.30-39.6$ & 28.4- 553.2 & $<0.001$ \\
\hline IQR & 39.9 & 16.9 & 8.53 & \\
\hline $95 \% \mathrm{CI}$ & $28.5-37.1$ & $19.2-23.1$ & $12.1-15.6$ & \\
\hline \multicolumn{5}{|c|}{ Leptin } \\
\hline $\operatorname{Median}(\mathrm{ng} / \mathrm{ml})$ & $4.19^{\mathrm{a}}$ & $2.2^{b}$ & $0.99^{b}$ & $<0.001$ \\
\hline Range & $0.9-19.8$ & $0.07-34.0$ & $0.02-22.0$ & \\
\hline IQR & 0.82 & 1.85 & 0.76 & \\
\hline $95 \% \mathrm{CI}$ & $4.2-5.6$ & $2.1-4.1$ & $0.8-3.3$ & \\
\hline \multicolumn{5}{|c|}{ Visfatin } \\
\hline Median (ng/ml) & $156.0^{\mathrm{a}}$ & $35.0^{\mathrm{b}}$ & $21.0^{\mathrm{c}}$ & $<0.001$ \\
\hline Range & $12.7-218$ & $8.5-50$ & $2.0-50$ & \\
\hline IQR & 53 & 7 & 7.5 & \\
\hline $95 \% \mathrm{CI}$ & $138.5-157.0$ & $33.7-36.3$ & $20.1-25.1$ & \\
\hline \multicolumn{5}{|c|}{ AFP } \\
\hline Median (ng/ml) & $272.0^{\mathrm{a}}$ & $7.5^{b}$ & $5.4^{\mathrm{b}}$ & \\
\hline Range & 1.9- 11884 & $1.0-146$ & $2.6-9.6$ & $<0.001$ \\
\hline IQR & 1173 & 9 & 3.45 & \\
\hline $95 \% \mathrm{CI}$ & $1414.0-9315.7$ & $10.1-18.6$ & $5.0-6.1$ & \\
\hline
\end{tabular}

increased serum level of visfatin associated significantly with the increased mortality of the patients $(\mathrm{P}<0.001)$. No significant relations were found between the serum levels of adiponectin, leptin, visfatin and the age of the patients $(\mathrm{P}=0.61,0.89$ and 0.50 ; respectively), residence $(\mathrm{P}=0.16,0.97$ and 0.28 ; respectively), $\mathrm{BMI}(\mathrm{P}=0.69$, 0.63 and 0.68 ; respectively), the presence of ascites $(\mathrm{P}=0.33,0.32$ and 0.61 ; respectively), BCLC $(\mathrm{P}=0.38$, 0.22 and 0.77 ; respectively), tumor size $(\mathrm{P}=0.21,0.30$ and 0.14 ; respectively), metastasis $(\mathrm{P}=0.66,0.39$ and 0.20 ; respectively), or the presence of diabetes $(\mathrm{P}=0.44,0.78$ and 0.99; respectively, Table 4).

Correlation between the studied markers and the clinicopathological features of HCV patients

Serum levels of adiponectin, leptin and visfatin associated significantly with the presence of cirrhosis in $\mathrm{HCV}$ patients $(\mathrm{P}<0.001, \mathrm{P}=0.008, \mathrm{P}<0.001$; respectively). Also serum levels of adiponectin and visfatin associated significantly with the age of the patients. However, there were no significant association with other features like BMI and DM $(\mathrm{P}>0.05$, Table 5).

The diagnostic accuracy of serum adipokines and AFP for $\mathrm{HCC}$

To evaluate the diagnostic accuracy of serum adipokines in HCC patients, HCV and NC subjects, ROC curve analysis was performed. The AUC of serum adiponectin was $0.691(95 \% \mathrm{CI}=0.87-0.95)$, the sensitivity, specificity, PPV, NPV and accuracy were (88.2\%, 80.7\%, 72.1\%, 92.4\% and 83.4\%; respectively). The AUC of serum leptin was 0.875 (95\%CI=0.83-0.92). The sensitivity, specificity, PPV, NPV and accuracy were (98.8\%, 83.3\%, 77.1\%, 99.2\%and 88.9\%; respectively),
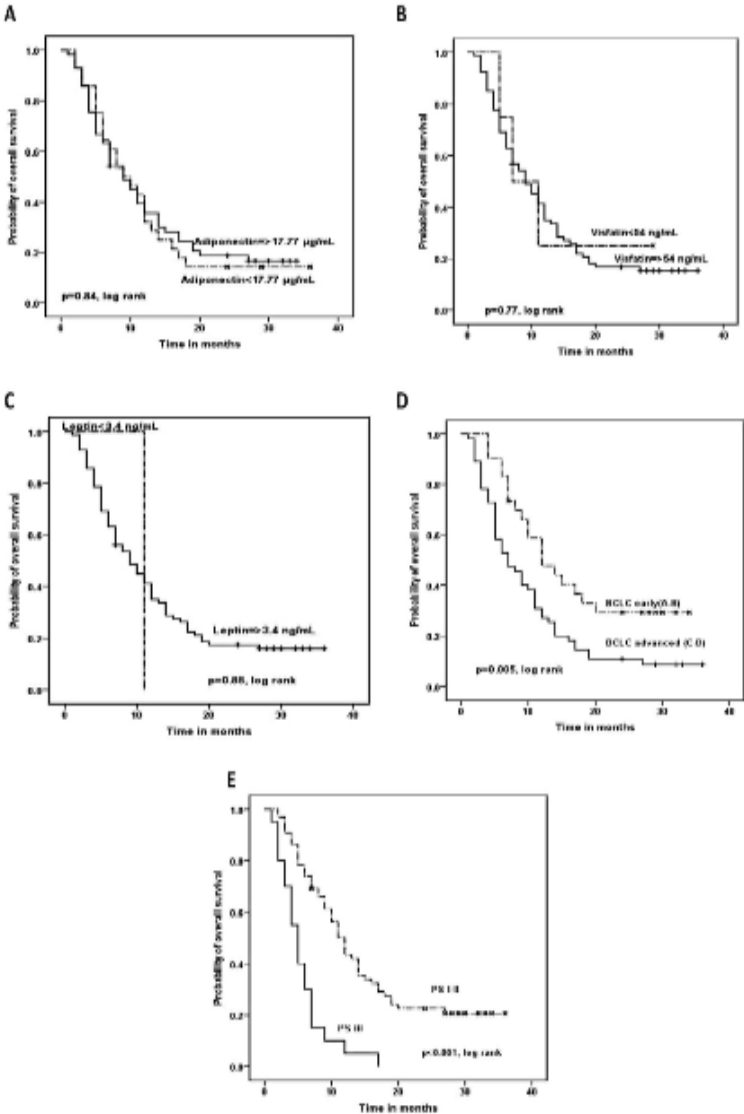

Figure 5. Kaplan Meier Aanalysis for the Overall Survival (OS) of HCC Patients.

where leptin achieved the highest sensitivity (98.8\%). While the AUC of the serum visfatin was 0.975 (95\%CI=0.95-1.0). The sensitivity, specificity, PPV, NPV and accuracy were $(95.3 \%, 100 \%, 100 \%, 97.4 \%$ and $98.3 \%$; respectively), where visfatin had the highest specificity and PPV (100\%). On the other hand, the AUC of the serum AFP was $0.910(95 \% \mathrm{CI}=0.87-0.95)$. whereas the sensitivity, specificity, PPV, NPV and accuracy were $(88.2 \%, 80.7 \%, 72.1 \%, 92.4 \%$ and $83.4 \%$; respectively, Table 6 and Figure 4).

By performing different combinations between adiponectin, leptin, visfatin and AFP for diagnosis of HCC patients. We found that leptin and visfatin combination achieved the highest sensitivity, specificity, PPV, NPV and accuracy $(100 \%, 96.6 \%, 93.4 \%, 100 \%$ and $97.4 \%$; respectively, Table 6 ).

\section{Overall survival analysis in HCC patients}

Kaplan Meier analysis for overall survival (OS) of HCC patients was done. PS of the patients associated significantly with shorter OS. The median OS of patients with PS I and II was 11 months versus 5 months for patients with PS III $(\mathrm{P}<0.001)$. Also advanced BCLC class associated significantly with shorter OS, where the median OS of patients with BCLC (A and B) versus those with advanced BCLC (C and D) were (12 and 7; respectively). On contrary, there were no significant impact of serum adipokine levels or AFP on the OS of the patients (Table 7 and Figure 5).

Multivariate analysis for OS showed that only BCLC Asian Pacific Journal of Cancer Prevention, Vol 21 
Table 4. Correlation between the Studied Markers and the Clinico-Pathological Features of the HCC Patients

\begin{tabular}{|c|c|c|c|c|c|c|}
\hline Characteristics & Adiponectin & $\mathrm{p}$ & Leptin & $\mathrm{p}$ & Visfatin & $\mathrm{p}$ \\
\hline \multicolumn{7}{|l|}{ Age } \\
\hline Age $<60(n=41)$ & $38.4(2.3-64.99)$ & $0.61^{\mathrm{a}}$ & $4.2(3.4-15.7)$ & $0.89^{\mathrm{a}}$ & $156(78-207)$ & $0.50^{\mathrm{a}}$ \\
\hline Age $\geq 60(n=44)$ & $36.1(2.95-67.4)$ & & $4.2(0.9-19.8)$ & & $155.5(12.7-218.0)$ & \\
\hline \multicolumn{7}{|l|}{ Residence } \\
\hline Rural (n=61) & $38.03(3.99-67.4)$ & $0.16^{\mathrm{a}}$ & $4.2(3.4-19.8)$ & $0.97^{\mathrm{a}}$ & $154(12.7-218)$ & $0.28^{\mathrm{a}}$ \\
\hline Urban $(n=24)$ & $33.6(2.3-62.7)$ & & $4.2(0.9-13.8)$ & & $166.5(28.8-198)$ & \\
\hline \multicolumn{7}{|l|}{ DM } \\
\hline Non Diabetic $(n=71)$ & $36.2(2.96-62.7)$ & $0.44^{\mathrm{a}}$ & $4.2(0.9-19.8)$ & $0.78^{a}$ & $156(28.8-218)$ & $0.99^{\mathrm{a}}$ \\
\hline Diabetic $(n=14)$ & $44.1(2.3-67.4)$ & & $3.8(3.4-15.7)$ & & $160.5(12.7-204)$ & \\
\hline \multicolumn{7}{|l|}{ BMI } \\
\hline Normal $(n=27)$ & $29.6(3.4-62.7)$ & $0.69^{\mathrm{b}}$ & $3.4(3.4-7.4)$ & $0.63^{\mathrm{b}}$ & $162(12.7-207)$ & $0.68^{\mathrm{b}}$ \\
\hline Overweight ( $\mathrm{n}=38)$ & $36.1(2.96-67.41)$ & & $4.2(0.9-19.8)$ & & $156(28.8-204)$ & \\
\hline Class I obesity $(n=14)$ & $40.4(2.3-59.5)$ & & $4.2(4.3 .8-18.7)$ & & $160.5(33-193)$ & \\
\hline Class II obesity $(n=6)$ & $44.5(4.02-55.5)$ & & $3.8(3.4-15.7)$ & & $126(43-218)$ & \\
\hline \multicolumn{7}{|l|}{ Ascites } \\
\hline No $(n=54)$ & $36.1(2.3-67.4)$ & $0.33^{\mathrm{a}}$ & $3.8(3.4-19.8)$ & $0.32^{\mathrm{a}}$ & $155(12.8-218)$ & $0.61^{\mathrm{a}}$ \\
\hline Yes $(n=31)$ & $38.4(2.96-64.99)$ & & $4.2(0.9-18.7)$ & & $156.8(78-204)$ & \\
\hline \multicolumn{7}{|l|}{ Child-class } \\
\hline $\mathrm{I}(\mathrm{n}=20)$ & $14.2(2.3-59.5)$ & $0.03 * \mathrm{~b}$ & $3.4(3.4-6.6)$ & $0.53^{\mathrm{b}}$ & $170(43-193)$ & $0.62^{\mathrm{b}}$ \\
\hline II $(\mathrm{n}=45)$ & $40.8(2.96-67.4)$ & & $4.2(0.9-19.8)$ & & $151(12.8-218)$ & \\
\hline III $(n=20)$ & $38.4(4.3-62.7)$ & & $3.8(3.4-13.1)$ & & $157.9(33-207)$ & \\
\hline \multicolumn{7}{|l|}{ Performance status (ECOG) } \\
\hline $0(\mathrm{n}=16)$ & $14.4(4.02-58.3)$ & $0.02 * \mathrm{~b}$ & $3.8(3.4-8.1)$ & $0.74^{\mathrm{b}}$ & $168.5(43.0-193.0)$ & $0.85^{\mathrm{b}}$ \\
\hline $1(\mathrm{n}=22)$ & $37.2(2.3-63.8)$ & & $3.8(0.9-19.8)$ & & $152.5(89.0-193.0)$ & \\
\hline $2(\mathrm{n}=34)$ & $38.6(2.9-67.4)$ & & $4.2(3.8-18.7)$ & & $154(12.7-198.0)$ & \\
\hline $3(n=13)$ & $49.8(9.5-64.9)$ & & $4.2(3.4-13.7)$ & & $159(95-218)$ & \\
\hline \multicolumn{7}{|l|}{ Number of lesions } \\
\hline Single $(n=20)$ & $29.3(2.3-51.7)$ & $0.11^{\mathrm{b}}$ & $4.2(3.2-18.7)$ & $0.006^{* b}$ & $163.4(12.7-187)$ & $0.70^{\mathrm{b}}$ \\
\hline Bifocal $(n=6)$ & $33.3(7.8-55.5)$ & & $6.2(4.2-15.7)$ & & $145.5(100.6-180)$ & \\
\hline Multiple ( $\mathrm{n}=59$ ) & $38.9(3.4-67.4)$ & & $3.4(0.9-19.8)$ & & $156(33-218)$ & \\
\hline \multicolumn{7}{|l|}{ BCLC } \\
\hline$A(n=3)$ & $35.9(5.0-36.03)$ & $0.38^{\mathrm{b}}$ & $4.2(4.2-4.2)$ & $0.22^{\mathrm{b}}$ & $90(86-182)$ & $0.77^{\mathrm{b}}$ \\
\hline$B(n=27)$ & $37.8(4.02-63.8)$ & & $3.4(3.4-15.7)$ & & $152(43-198)$ & \\
\hline$C(n=43)$ & $36.2(2.3-67.4)$ & & $4.2(0.9-19.8)$ & & $165(12.7-218)$ & \\
\hline $\mathrm{D}(\mathrm{n}=12)$ & $40.1(4.8-64.9$ & & $4.2(3.4-13.7)$ & & $152(95-207)$ & \\
\hline \multicolumn{7}{|l|}{ Tumor size(cm) } \\
\hline$<3(\mathrm{n}=8)$ & $36.9(6.6-55.5)$ & $0.21^{\mathrm{b}}$ & $4.2(3.4-15.7)$ & $0.30^{\mathrm{b}}$ & $139.5(58-182)$ & $0.14^{\mathrm{b}}$ \\
\hline $3-5(n=11)$ & $28.9(2.3-47.9)$ & & $4.2(3.4-8.1)$ & & $156(28.8-184)$ & \\
\hline$>5(\mathrm{n}=66)$ & $38.3(2.9-67.4)$ & & $3.4(0.9-19.8)$ & & $163.5(12.7-218.0)$ & \\
\hline \multicolumn{7}{|l|}{ Metastasis } \\
\hline M0 (n=71) & $36.5(2.3-67.4)$ & $0.66^{\mathrm{a}}$ & $4.2(3.4-18.7)$ & $0.39^{\mathrm{a}}$ & $152(28.8-207)$ & $0.20^{\mathrm{a}}$ \\
\hline M1 (n=14) & $37.3(7.8-64.9)$ & & $3.4(0.9-19.8)$ & & $166.5(12.7-218)$ & \\
\hline \multicolumn{7}{|l|}{ Mortality } \\
\hline Alive $(n=15)$ & $36.5(4.02-60.75)$ & $0.73^{\mathrm{a}}$ & $4.2(3.4-15.7)$ & $0.64^{\mathrm{a}}$ & $109(43-182)$ & $<0.001 *$ \\
\hline Dead $(n=70)$ & $37.2(2.3-67.4)$ & & $3.8(0.9-19.8)$ & & $165(12.7-218.0)$ & \\
\hline
\end{tabular}

a, Mann whitney test; ${ }^{\text {b }}$ Kruskal Wallis test; *, Significance at $\mathrm{p}<0.05$ 
DOI:10.31557/APJCP.2020.21.3.599

The Possible Role of Adipokines in HCV Associated Hepatocellular Carcinoma

Table 5. Correlation between the Studied Markers and the Clinico-Pathological Features of the HCV Patients

\begin{tabular}{|c|c|c|c|c|c|c|c|c|}
\hline Parameters & Adiponectin & $\mathrm{p}$ & Leptin & $\mathrm{p}$ & Visfatin & & AFP & $\mathrm{P}$ \\
\hline Age & & $0.015^{\mathrm{a}}$ & & 0.83 & & 0.008 & & 0.98 \\
\hline$<60(73)$ & $17.7(0.3-37.5)$ & & $2.4(0.07-27.9)$ & & $35(8.5-43.0)$ & & $8(1-146)$ & \\
\hline$\geq 60(27)$ & $27(0.5-39.6)$ & & $2.1(0.5-34.0)$ & & $38(29-50)$ & & $6(1-77)$ & \\
\hline Gender & & $0.15^{\mathrm{a}}$ & & 0.24 & & 0.53 & & 0.75 \\
\hline Male (69) & $19.7(4.2-39.6)$ & & $2(0.07-34.0)$ & & $36(8.5-45)$ & & $7(1-146)$ & \\
\hline Female (31) & $25.8(0.3-37.5)$ & & $2.4(0.4-7.6)$ & & $35(10-50)$ & & $8(1-87)$ & \\
\hline $\mathrm{DM}$ & & $0.19^{\mathrm{a}}$ & & 0.5 & & 0.64 & & 0.52 \\
\hline Nondiabetic (70) & $19.8(0.3-39.6)$ & & $2.3(0.07-27.9)$ & & $35 \quad(8.5-46)$ & & $8(1-87)$ & \\
\hline Diabetic (30) & $26.5(0.5-37.0)$ & & $1.9(0.4-34.0)$ & & $36.5(10-50)$ & & $6(1-146)$ & \\
\hline BMI & & $0.48^{\mathrm{b}}$ & & 0.8 & & 0.94 & & 0.64 \\
\hline Normal (20) & $15(4.2-39.6)$ & & $2.2(0.4-9.4)$ & & $35(19-43)$ & & $6(1-55)$ & \\
\hline Overweight(50) & $20.1(0.5-37.6)$ & & $2.1(0.07-34.0)$ & & $35.5(8.5-50)$ & & $8(2-62)$ & \\
\hline Class I Obesity (25) & $20.2(0.3-38.9)$ & & $2.2(0.15-5.5)$ & & $36(10-43)$ & & $6(1-146)$ & \\
\hline Class II Obesity (5) & $24.1(13.2-35.9)$ & & $3(0.4-3.4)$ & & $33(25-45)$ & & $9(3-77)$ & \\
\hline Cirrhosis & & $<0.001^{\mathrm{a}}$ & & 0.008 & & $<0.001$ & & 0.3 \\
\hline Absent (52) & $14.7(0.3-34.3)$ & & $1.7(0.07-4.8)$ & & $34(8.5-43)$ & & $5.5(1-87)$ & \\
\hline Present (48) & $29.6(10.1-39.6)$ & & $2.4(1.2-34.0)$ & & $38(26-50)$ & & $9(1-146)$ & \\
\hline
\end{tabular}

${ }^{\text {a, }}$ Mann whitney, ${ }^{\text {b. Kruskal wallis }}$

is an independent prognostic factor for OS (Table 8).

\section{Discussion}

The NAFLD associated HCC incidence is increasing worldwide in parallel with obesity epidemic (Said and Ghufran, 2017). However, few studies investigated the adipokines levels and HCC risk among patients with HBV and/or HCV (Chen et al., 2014; Tsai et al., 2017). In the corresponding study, we evaluated the prognostic and the predictive roles of adiponectin, leptin and visfatin in $\mathrm{HCV}$ associated HCC patients, chronic HCV patients and normal control subjects, with a specific aim of identifying different pathways that may be implicated in the pathogenesis of HCV associated HCC.
Till now, there is a discrepancy in the published data regarding the level of adiponectin in HCC patients. Our results demonstrate a significant increase in the serum level of adiponectin in $\mathrm{HCC}$ and $\mathrm{HCV}$ patients compared to the NC groups. We also found a significant association between the elevated serum level of adiponectin and advanced Child class liver cirrhosis as well as with poor ECOG performance status of the tested patients. These data are in agreement with the other previously published data in the literature reported that higher adiponectin level associated significantly with increased risk of HCC (Chen et al., 2014; Song and Gu, 2015), advanced liver disease (Kaser et al., 2005; Liu et al., 2009) and predicts worse patients' prognosis (Wang et al., 2014; Siegel et al., 2015;). Similarly, Chen et al., (2012) performed a

Table 6. The Diagnostic Accuracy of ROC-Curve Analysis for the Different Studied Markers

\begin{tabular}{lcccccccc}
\hline & Cutoff & AUC & SE (95\%CI) & Sensitivity & Specificity & PPV & NPV & Accuracy \\
\hline AFP & 10.5 & 0.91 & $0.022(0.87-0.95)$ & 88.2 & 80.7 & 72.1 & 92.4 & 83.4 \\
Adiponectin & 17.8 & 0.691 & $0.044(0.60-0.78)$ & 67.1 & 54.7 & 45.6 & 74.5 & 59.1 \\
Leptin & 3.36 & 0.875 & $0.024(0.83-0.92)$ & 98.8 & 83.3 & 77.1 & 99.2 & 88.9 \\
visfatin & 54 & 0.975 & $0.015(0.95-1.0)$ & 95.3 & 100 & 100 & 97.4 & 98.3 \\
Adiponectin+leptin & 0.4667 & 0.838 & $0.026(0.79-0.89)$ & 100 & 75.2 & 69.7 & 100 & 83.8 \\
Adiponectin+ visfatin & 0.6407 & 0.98 & $0.007(0.97-0.99)$ & 94.1 & 90 & 84.2 & 96.4 & 91.5 \\
leptin+visfatin & 0.351 & 0.976 & $0.011(0.95-1.0)$ & 100 & 96.6 & 93.4 & 100 & 97.4 \\
Adiponectin+leptin+visfatin & 0.4257 & 0.982 & $0.007(0.97-1.0)$ & 100 & 92 & 87.6 & 100 & 94.9 \\
AFP+ Adiponectin & 0.1616 & 0.91 & $0.023(0.87-0.95)$ & 88.2 & 80 & 71.4 & 92.3 & 83 \\
AFP+ leptin & 0.157 & 0.954 & $0.012(0.93-0.98)$ & 89.4 & 86 & 78.4 & 93.5 & 96.2 \\
AFP+ visfatin & 0.1218 & 0.977 & $0.009(0.96-1.0)$ & 92.7 & 90.7 & 84.9 & 95.8 & 91.5 \\
AFP+ adiponectin+leptin & 0.16139 & 0.945 & $0.015(0.92-0.97)$ & 89.4 & 88.7 & 81.7 & 93.7 & 88.9 \\
AFP+ adiponectin+visfatin & 0.1338 & 0.967 & $0.013(0.94-0.99)$ & 92.9 & 91.3 & 85.9 & 95.8 & 91.9 \\
AFP+ leptin+visfatin & 0.10249 & 0.987 & $0.006(0.98-1.0)$ & 96.5 & 93.3 & 89.1 & 97.9 & 94.5 \\
AFP+ adiponectin+leptin+visfatin & 0.1028 & 0.98 & $0.008(0.96-1.0)$ & 95.3 & 91.3 & 86.2 & 97.2 & 92.8 \\
\hline
\end{tabular}


Table 7. Overall Survival Analysis for HCC Patients

\begin{tabular}{|c|c|c|c|c|c|}
\hline \multirow[t]{2}{*}{ Factor } & \multirow[t]{2}{*}{ No } & \multicolumn{3}{|c|}{ OS } & \multirow[t]{2}{*}{$P$} \\
\hline & & $\%$ & Median & $95 \% \mathrm{CI}$ & \\
\hline Total & & 17.6 & NA & NA & NA \\
\hline Age & & & & & 0.52 \\
\hline$<60$ & 41 & 19.5 & 10 & $7.0-13.0$ & \\
\hline$\geq 60$ & 44 & 15.9 & 7 & $4.2-9.8$ & \\
\hline Gender & & & & & 0.19 \\
\hline Male & 68 & 14.7 & 9 & $6.6-11.4$ & \\
\hline Female & 17 & 29.4 & 14 & $5.2-22.7$ & \\
\hline Residence & & & & & 0.26 \\
\hline Rural & 61 & 19.7 & 11 & $8.3-13.7$ & \\
\hline Urban & 24 & 12.5 & 6 & $3.9-8.1$ & \\
\hline BMI & & & & & 0.37 \\
\hline Normal & 27 & 18.5 & 7 & $2.0-12.0$ & \\
\hline $\begin{array}{l}\text { Overweight- } \\
\text { Obese }\end{array}$ & 58 & 17.2 & 10 & $6.8-13.2$ & \\
\hline PS & & & & & $<0.001 *$ \\
\hline I-II & 65 & 23.1 & 11 & $9.1-12.9$ & \\
\hline III & 20 & 0 & 5 & $3.6-6.4$ & \\
\hline Tumor size $(\mathrm{cm})$ & & & & & 0.15 \\
\hline$\leq 5$ & 19 & 26.3 & 12 & $5.2-18.8$ & \\
\hline$>5$ & 66 & 15.2 & 8 & $5.6-10.3$ & \\
\hline Child class & & & & & 0.09 \\
\hline A & 54 & 20.4 & 11 & $8.4-13.6$ & \\
\hline B & 31 & 12.9 & 6 & $4.0-8.0$ & \\
\hline BCLC & & & & & $0.005^{*}$ \\
\hline Early (A-B) & 30 & 33.3 & 12 & $6.9-17.0$ & \\
\hline Advanced (C-D) & 55 & 9.1 & 7 & $4.1-9.9$ & \\
\hline Lobe & & & & & 0.55 \\
\hline 1 & 20 & 20 & 10 & $5.6-14.4$ & \\
\hline $2-3$ & 65 & 16.9 & 9 & $6.2-11.8$ & \\
\hline Metastasis & & & & & 0.34 \\
\hline M0 & 71 & 19.7 & 10 & 7.4-12.6 & \\
\hline M1 & 14 & 7.1 & 7 & $5.2-8.8$ & \\
\hline AFP & & & & & 0.22 \\
\hline$<10.5$ & 10 & 30 & 12 & 7.4-16.6 & \\
\hline$\geq 10.5$ & 75 & 16 & 9 & $6.8-11.2$ & \\
\hline Adiponectin (/ml) & & & & & 0.84 \\
\hline$<17.77$ & 28 & 14.3 & 9 & $4.9-13.1$ & \\
\hline$\geq 17.77$ & 57 & 19.3 & 9 & $6.3-11.7$ & \\
\hline Leptin (ng/ml) & & & & & 0.88 \\
\hline$<3.36$ & 1 & 0 & 11 & NA & \\
\hline$\geq 3.36$ & 84 & 17.9 & 9 & $6.2-11.9$ & \\
\hline Visfatin (ng/ml) & & & & & 0.77 \\
\hline$<54.0$ & 4 & 25 & 7 & $1.1-12.9$ & \\
\hline$\geq 54.0$ & 81 & 17.3 & 9 & $6.2-11.8$ & \\
\hline
\end{tabular}

study on HCC patients' tissues, he found that increased adiponectin level correlated significantly with tumor size, indicating its possible role as a prognostic factor in those patients. In contrast to the previously mentioned studies, Shin et al., (2014) reported a significant relationship
Table 8. Multivariate Survival Analysis for HCC Patients

\begin{tabular}{lccc}
\hline Factors & \multicolumn{3}{c}{ Overall survival } \\
& HR & $95 \%$ CI & P-value \\
\hline PS III vs I-II & 1.61 & $0.93-2.80$ & 0.09 \\
BCLC C-D vs A-B & 2.96 & $1.7-5.3$ & $<0.001 *$ \\
\hline a, Cox regression; *Significance at $\mathrm{p}<0.05$ &
\end{tabular}

between adiponectin and favorable prognosis in $\mathrm{HCC}$ patients. Similarly, Starley et al., (2010) and Bråkenhielm et al., (2004) reported decreased amount of adiponectin in HCC patients. They demonstrated in their studies that adiponectin inhibits angiogenesis and primary tumor growth through inhibition of neovascularization and enhancement of tumor cell apoptosis (Shin et al., 2014; Wong et al., 2016). Although the molecular and biological mechanisms explaining the association between increased adiponectin and reduced survival in HCC patients are not clearly understood, possible explanations for this association includes reduced liver function e.g. elevated liver enzymes (Wang et al., 2014), since the adiponectin level reflects the severity of liver fibrosis (Liu et al., 2009) and cirrhosis (Kaser et al., 2005) which are correlated with consequent poorer prognosis.

Our data also show a significant increase in the serum levels of visfatin in $\mathrm{HCC}$ and $\mathrm{HCV}$ patients compared to the NC groups. These data are in concordance with these of Ninomiya et al., (2011) and Liang et al., (2018) who found that visfatin level is significantly higher in HCC patients compared to control group, and that it induces HCC cell migration via upregulation of miR-21. In our study, we found that increased serum level of visfatin associates significantly with increased mortality rates of the patients. These results are in concordance with that reported by Tsai et al., (2017) who found that visfatin level correlates significantly with tumor size, LN metastasis and shorter survival time. Hence it could be considered a poor prognostic marker of HCC patients.

Regarding the serum level of leptin, our data demonstrated a significant increase in its level in HCC patients compared to the other tested groups, whereas there were no significant differences in its level between $\mathrm{HCV}$ and NC. These data are in agreement with those reported by Watanabe et al., (2011) that leptin can cause tumor growth, and associates with $\mathrm{HCC}$ recurrence after treatment. Since it has an important role in carcinogenesis, cancer cell survival, proliferation and migration (Booth et al., 2015). It also increases the expression levels of antiapoptotic proteins, inflammatory markers (TNF-a, IL-6), angiogenic factors (VEGF), and the hypoxia-inducible factor-1a (HIF-1a) (Sharma et al., 2006). This was correlated with our finding that Leptin overexpression was significantly associated with increased number of the lesions in the liver. However, these data are not in agreement with Chen et al., (2014) who conducted a prospective study in Taiwan, and reported no significant association between the serum levels of leptin or visfatin and increased risk of HCC.

The overall survival analysis of HCC patients showed that only PS and BCLC associate significantly with OS. 
Meanwhile, no significant impact is present for serum adiponectine, leptin, visfatin or AFP on the OS of the patients. These results are in concordance with those of Shen et al., (2016), and in contrast with those of Sun et al., (2017) who reported that HCC patients with high serum visfatin levels had significantly shorter OS times compared to those with low serum visfatin levels.

Many previous studies addressed the role of adipokines and obesity in the pathogenesis of NAFLD and HCC (Noureddin and Rinella, 2015; Perumpail et al., 2015), however none of these investigate their role in HCV chronic hepatitis and its progression to HCC. In the current study we investigated this point, we found a significant increase in the serum levels of adiponecine, leptin and visfatin in $\mathrm{HCV}$ chronic hepatitis patients compared to normal control. Our data in this context confirm the data of Tsai et al., (2017), who reported increased serum visfatin level in HCC patients with HBV or HCV infection. It was demonstrated that hepatic steatosis, along with obesity and diabetes mellitus (DM), increase the risk of HCC in patients with chronic HCV (Nam, 2017). Our data show significant differences between those three studied groups regarding DM, since $30 \%$ of the patients had DM in the $\mathrm{HCV}$ group, compared to $16.5 \%$ in $\mathrm{HCC}$, and $32 \%$ in the NC. These data were consistent with Konishi et al., (2009) from Japan. Thus, DM may have a role in the pathogenesis of chronic HCV hepatitis.

Other studies from japan reported that the risk of $\mathrm{HCC}$ in chronic HCV patients increases in overweight and obese patients compared to those underweight, hence increased BMI and obesity represent independent risk factors for HCC development in chronic HCV (Ohata et al., 2003; Ohki et al., 2008). In contrary, our data show no significant differences between the three tested groups regarding $\mathrm{BMI}$, since the mean $\mathrm{BMI}$ in $\mathrm{HCC}, \mathrm{HCV}$ and $\mathrm{NC}$ was $(27.2 \pm 4.95,28.4 \pm 4.1$ and $28.6 \pm 6.6$; respectively), and the mean body weight was $(75.8 \pm 14.4,79.3 \pm 13.3$ and $76.7 \pm 16.8$; respectively). Thus we assume that the increased serum levels of adiponecine, leptin and visfatin in $\mathrm{HCC}$ and $\mathrm{HCV}$ patients are possibly due to mechanisms other than obesity, and thus further studies are highly required to investigate the role of these adipokines in the pathogenesis of $\mathrm{HCV}$, and the development of $\mathrm{HCC}$. Furthermore, we observed a significant association between the serum levels of adiponectin, leptin and visfatin with the presence of cirrhosis in HCV patients. Meanwhile, there were no significant association with the BMI or a history of DM. These results confirm those of Sun et al., (2017) who reported increased serum visfatin level in HBV associated HCC in patients who have $\mathrm{BMI}<25 \mathrm{~kg} / \mathrm{m}^{2}$. Therefore, further studies on a large number of patients are required to exactly determine the role of adipokines in HCC obese patients.

Similar to the classical cytokines, adipocytokines have many pro-inflammatory functions, as they increase the production of IL-6, TNF- $\alpha$, and IL-12 (Moschen et al., 2007). overexpression of visfatin increases the activity of a number of signaling pathways that promote carcinogenesis e.g. NAD-dependent SIRTs, PI3K/ Akt, ERK1/2, and STAT3 (Bi and Che, 2010).

According to our data, assessment of the serum levels of adiponecine, leptin and visfatin increase the diagnostic accuracy of HCC patients, leptin has the highest sensitivity (98.8\%), and visfatin has the highest specificity and PPV $(100 \%)$. However, these data are not consistent with Sun et al., (2017), who reported $45.76 \%$ sensitivity, and $74.79 \%$ specificity values of serum visfatin for the diagnosis of HCC.

We recommend using a combination of serum leptin and visfatin for the diagnosis and prediction of $\mathrm{HCV}$ associated HCC patients, as the sensitivity, specificity, PPV, NPV and accuracy were (100\%, 96.6\%, 93.4\%, $100 \%$ and $97.4 \%$; respectively).

In conclusion, serum levels of adiponecine, leptin and visfatin increased significantly in $\mathrm{HCC}$ and $\mathrm{HCV}$ infected patients compared to the normal control subjects. Moreover, these markers are significantly associated with the presence of cirrhosis in HCV patients, despite there were no significant differences in the BMI among patients' groups. Therefore, another mechanism(s) may be responsible for the elevation of these adipokines in the $\mathrm{HCV}$ associated HCC other than obesity. The combination of serum leptin and visfatin could be used as potential biomarkers for early detection and diagnosis of patients with HCV associated HCC. Further studies are still required on larger number of patients to confirm the role of these markers in HCC, also in the other malignancies.

\section{Acknowledgments}

This work was supported by Science and Technology Development Fund \#5193 to Abdel-Rahman N. Zekri and Egypt National Cancer Institute.

\section{Compliance with Ethical Standards}

The study protocol was approved by the Ethical Committee of the NCI, Egypt, which was in accordance with 2011 declaration of Helsinki. A signed informed consent was obtained from all participants before enrollment in the study.

\section{Competence of interest}

All authors declare that there is no conflict of interest regarding this manuscript.

\section{References}

Amin MB, Greene FL, Edge SB, et al (2017). The Eighth Edition AJCC Cancer Staging Manual: Continuing to build a bridge from a population-based to a more "personalized" approach to cancer staging. CA Cancer J Clin, 67, 93-9.

Bi TQ, Che XM (2010). Nampt/PBEF/visfatin and cancer. Cancer Biol Ther, 10, 119-25.

Booth A, Magnuson A, Fouts J, Foster M (2015). Adipose tissue, obesity and adipokines: role in cancer promotion. Horm Mol Biol Clin Investig, 21, 57-74.

Boutari C, Perakakis N, Mantzoros CS (2018). Association of adipokines with development and progression of nonalcoholic fatty liver disease. Endocrinol Metab. 33(1), 33-43.

Bråkenhielm E, Veitonmäki N, Cao R, et al (2004). Adiponectin-induced antiangiogenesis and antitumor activity involve caspase-mediated endothelial cell apoptosis. 
Proc Natl Acad Sci U S A, 101, 2476-81.

Chen CL, Yang WS, Yang HI, et al (2014). Plasma adipokines and risk of hepatocellular carcinoma in chronic hepatitis B virus-infected carriers: A prospective study in Taiwan. Cancer Epidemiol Biomarkers Prev, 23, 1659-71.

Chen MJ, Yeh YT, Lee KT, et al (2012). The promoting effect of adiponectin in hepatocellular carcinoma. J Surg Oncol, 106, 181-7.

Deng T, Lyon CJ, Bergin S, Caligiuri MA, Hsueh WA (2016). Obesity, inflammation, and cancer. Annu Rev Pathol Mechanisms Dis, 11, 421-49.

Ferre P, Foufelle F (2010). Hepatic steatosis: a role for de novo lipogenesis and the transcription factor SREBP-1c. Diabetes Obes Metab, 12, 83-92.

Ibrahim AS, Khaled HM, Mikhail NN, Baraka H, Kamel H (2014). Cancer incidence in Egypt: results of the national population-based cancer registry program. J Cancer Epidemiol, 2014, 1-18.

Ikejima K, Honda H, Yoshikawa M, et al (2001). Leptin augments inflammatory and profibrogenic responses in the murine liver induced by hepatotoxic chemicals. Hepatology, 34, 288-97.

Kakuma T, Lee Y, Higa M, et al (2000). Leptin, troglitazone, and the expression of sterol regulatory element binding proteins in liver and pancreatic islets. Proc Natl Acad Sci U S A, 97, 8536-41.

Kaser S, Moschen A, Kaser A, et al (2005). Circulating adiponectin reflects severity of liver disease but not insulin sensitivity in liver cirrhosis. J Int Med, 258, 274-80.

Konishi I, Hiasa Y, Shigematsu S, et al (2009). Diabetes pattern on the $75 \mathrm{~g}$ oral glucose tolerance test is a risk factor for hepatocellular carcinoma in patients with hepatitis $\mathrm{C}$ virus. Liver Int, 29, 1194-1201.

Liang N, Chen Y, Yang L, He S, Liu T (2018). Visfatin increases miR-21 to promote migration in HCC. Cell Mol Biol (Noisy-le-Grand, France), 64, 48-52.

Liu CJ, Chen PJ, Lai MY, et al (2009). High serum adiponectin correlates with advanced liver disease in patients with chronic hepatitis B virus infection. Hepatol Int, 3, 364-70.

Macis D, Guerrieri-Gonzaga A, Gandini S (2014). Circulating adiponectin and breast cancer risk: a systematic review and meta-analysis. Int $J$ Epidemiol, 43, 1226-36.

Matarese G, Procaccini C, De Rosa V, Horvath TL, La Cava A (2010). Regulatory T cells in obesity: the leptin connection. Trends Mol Med, 16, 247-56.

Moschen AR, Kaser A, Enrich B, et al (2007). Visfatin, an adipocytokine with proinflammatory and immunomodulating properties. J Immunol, 178, 1748-58.

Nam SY (2017). Obesity-related digestive diseases and their pathophysiology. Gut Liver, 11, 323.

Ninomiya S, Shimizu M, Imai K, et al (2011). Possible role of visfatin in hepatoma progression and the effects of branchedchain amino acids on visfatin-induced proliferation in human hepatoma cells. Cancer Prev Res, 4, 2092-100.

Noureddin M, Rinella ME (2015). Nonalcoholic fatty liver disease, diabetes, obesity, and hepatocellular carcinoma. Clin Liver Dis, 19, 361-79.

Ohata K, Hamasaki K, Toriyama K, et al (2003). Hepatic steatosis is a risk factor for hepatocellular carcinoma in patients with chronic hepatitis $\mathrm{C}$ virus infection. Cancer, 97, 3036-43.

Ohki T, Tateishi R, Sato T, et al (2008). Obesity is an independent risk factor for hepatocellular carcinoma development in chronic hepatitis C patients. Clin Gastroenterol Hepatol, 6, 459-64.

Otani K, Ishihara S, Yamaguchi H, et al (2017). Adiponectin and colorectal cancer. Surg Today, 47, 151-8.
Perumpail RB, Liu A, Wong RJ, Ahmed A, Harrison SA (2015). Pathogenesis of hepatocarcinogenesis in non-cirrhotic nonalcoholic fatty liver disease: Potential mechanistic pathways. World J Hepatol, 7, 2384.

Polyzos SA, Kountouras J, Zavos C, Tsiaousi E (2010). The role of adiponectin in the pathogenesis and treatment of non-alcoholic fatty liver disease. Diabetes Obes Metab, 12, 365-83.

Said A, Ghufran A (2017). Epidemic of non-alcoholic fatty liver disease and hepatocellular carcinoma. World J Clin Oncol, 8, 429.6.

Said A, Ghufran A (2017). Epidemic of non-alcoholic fatty liver disease and hepatocellular carcinoma. World J Clin Oncol, 8, 429.

Saxen NK, Anania FA (2015). Adipocytokines and hepatic fibrosis. Trends Endocrinol Metab, 26, 153-61.

Sharma D, Saxena NK, Vertino PM, Anania FA (2006). Leptin promotes the proliferative response and invasiveness in human endometrial cancer cells by activating multiple signal-transduction pathways. Endocr Relat Cancer, 13, 629-40.

Shen J, Yeh CC, Wang Q, et al (2016). Plasma adiponectin and hepatocellular carcinoma survival among patients without liver transplantation. Anticancer Res, 36, 5307-14.

Shin E, Yu YD, Kim DS, Won NH (2014). Adiponectin receptor expression predicts favorable prognosis in cases of hepatocellular carcinoma. Pathol Oncol Res, 20, 667-75.

Siegel AB, Goyal A, Salomao M, et al (2015). Serum adiponectin is associated with worsened overall survival in a prospective cohort of hepatocellular carcinoma patients. Oncology, 88, 57-68.

Siegel RL, Miller KD, Fedewa SA, et al (2017). Colorectal cancer statistics, 2017. CA Cancer J Clin, 67, 177-93.

Song RR, Gu XL (2015). Serum adiponectin levels may be associated with the pathogenesis of hepatocellular carcinoma. Tumor Biol, 36, 2983-92.

Starley BQ, Calcagno CJ, Harrison SA (2010). Nonalcoholic fatty liver disease and hepatocellular carcinoma: a weighty connection. Hepatology, 51, 1820-32.

Stolzenberg-Solomon RZ, Newton CC, Silverman DT, et al (2015). Circulating leptin and risk of pancreatic cancer: a pooled analysis from 3 cohorts. Am J Epidemiol, 182, 187-97.

Stuyver L, Wyseur A, van Arnhem WO, Hernandez F, Maertens $G$ (1996). Second-generation line probe assay for hepatitis C virus genotyping. J Clin Microbiol, 34, 2259-66.

Sun Y, Zhu S, Wu Z, et al (2017). Elevated serum visfatin levels are associated with poor prognosis of hepatocellular carcinoma. Oncotarge, 8, 23427.

Tsai IT, Wang CP, Yu TH, et al (2017). Circulating visfatin level is associated with hepatocellular carcinoma in chronic hepatitis $\mathrm{B}$ or $\mathrm{C}$ virus infection. Cytokine, 90, 54-59.

Wang SN, Yang SF, Tsai HH, Lee KT, Yeh YT (2014). Increased adiponectin associated with poor survival in hepatocellular carcinoma. J Gastroenterol, 49, 1342-51.

Watanabe N, Takai K, Imai K, et al (2011). Increased levels of serum leptin are a risk factor for the recurrence of stage I/ II hepatocellular carcinoma after curative treatment. J Clin Biochem Nutr, 49, 153-8.

WHO (2016). Fact sheet No 164, July 2016. http://www.who. int/mediacentre/factsheets/fs164/ en/, accessed December 26, 2016.

Wong CR, Nguyen MH, Lim JK (2016). Hepatocellular carcinoma in patients with non-alcoholic fatty liver disease. World J Gastroenterol, 22, 8294.

World Health Organization (2016). Global health sector strategy on viral hepatitis 2016-2021. Towards ending viral hepatitis 
(No. WHO/HIV/2016.06). World Health Organization.

Ye J, Jia J, Dong S, et al (2014). Circulating adiponectin levels and the risk of breast cancer: a meta-analysis. Eur J Cancer Prev, 23, 158-65.

Zekri AR, Bakr YM, Ezzat MM, Zakaria MS, Elbaz TM (2015). Circulating levels of adipocytokines as potential biomarkers for early detection of colorectal carcinoma in Egyptian patients. Asian Pac J Cancer Prev, 16, 6923-8.

Zekri AR, Hassan ZK, Bahnassy AA, et al (2012). Molecular prognostic profile of Egyptian HCC cases infected with hepatitis C virus. Asian Pac J Cancer Prev, 13, 5433-8.

Zekri AR, Bahnassy AA, Ramadan AS, et al (2001). Hepatitis $\mathrm{C}$ virus genotyping versus serotyping in Egyptian patients. Infection, 29, 24-6.

\section{c) (7) (6)}

This work is licensed under a Creative Commons AttributionNon Commercial 4.0 International License. 